\title{
ПРИПОВЕДАЧКА ПРОЗА ГРИГОРИЈА БОЖОВИЋА У СВЕТЛУ ТРАДИЦИЈЕ
}

Филозофски факултет, Косовска Митровица

\begin{abstract}
Апстракт: Григорије Божовић је писац који је у свом књижевном опусу оставио богату слику живота Срба у Старој Србији. Његове приповетке и путописи представљају модерну прозу, али је писац у ове књижевне жанрове пренео богато традиционално наслеђе патријархалне културе у којој је рођен, а која је чувала архаичне облике колективне свести. У раду ћемо показати на који начин је Григорије Божовић транспоновао поједине облике традиционалне културе у уметнички текст, као што су праг, огњиште и земља, преко којих је створена јаснија слика о средини, људима и историјским приликама у којима је српски народ под турском влашћу вековима одолевао и чувао свој идентитет.
\end{abstract}

Кључне речи: лирска песма, епска песма, праг, огњиште, гост, земља, Срби, Турци, Арбанаси

Григорије Божовић рођен је у Ибарском Колашину и припада реду оних националних радника који ће уприповедачкој прози оставити дубок траг у сликању живота у Старој Србији и Македонији. У свом богатом књижевном опусу бавио се индивидуалним и колективним духом Косоваца који су остајали на земљи и онда кад је све било уперено против њих. У свом књижевном стваралаштву указивао је на историјске, антрополошке, етнопсихолошке, социолошке, лингвистичке и друге слојеве друштвеног живота. Захваљујући његовом књижевном опусу, можемо да извршимо реконструкцију архаичних слојева традиције $\mathrm{e}^{1}$ различитих етнопсихолошких заједница.

Станислав Винавер скренуо је пажњу на појаву талентованог писца с југа који је своје прве приповетке публиковао по листовима и часописима, наглашавајући да би објављивање његових приповедака требало да буде „најпреча дужност Књижевне задруге“ (Винавер 1924: 4). У Мостару је 1908. године објављена његова прва збирка

1 „Назив традиција потиче од латинског глагола trado, tradere у значењу предати, дати, давати даље, предати у руке, односно његовог именског адеквата tradition који значи предање везано за усмену традицију приповедања, обичајну праксу, веровања и животне обрасце. Српски назив за тај шири аспект наследства стеченог предајом јесте $\delta а ш \bar{u} и н а$, који у смислу непосредног наследства значи очевину, родно место. У том смислу предање није само усмена духовна култура већ и знање и вредности садржине у обрасцима мишљења и понашања који су изабрани из дотадашњег искуства да би се пренели наследницима" (Јовановић 2014: 38). 
приповедака Из Сйаре Србије. Било је то време смене књижевних епоха. Реализам, који је трајао од 1860. До 1910. године (Вученов 1981: 64), полако уступа место модерној књижевности на чијем фону ће стварати Григорије Божовић. Рођен у патријархалној средини, „однегован на десетерцу“, како је сам говорио, у кући, која је била „зборно место Колашинаца“, одмалена је упијао колективно наслеђе својих предака, наглашавајући да је то била средина у којој је народ живео од православља и то „оног простог православља“ (Зуковић 2006: 123).

Григорије Божовић је у свој књижевни опус транспоновао слојеве народне традиције и богато предачко наслеђе (Ћосић 1927: 73-76). Важно је напоменути да је оставио значајне податке о средини која је чувала архаичне облике колективне свести, негујући византијско наслеђе, које је под турском влашћу резултирало стварањем посебног варијетета, о коме је писао Јован Цвијић (Цвијић 1991: 325-517). Григорије Божовић је рођен у средини динарског варијетета ${ }^{2}$ која је неговала епско наслеђе, али је врло радо путовао и обилазио крајеве јужно од Ибра, који припадају централном типу карактерологије Срба ${ }^{3}$, с изразито лирским обележјем. Богато усмено наслеђе уз које је растао одредиће га и као човека и као писца (Зуковић 2006:123). У његовом стваралаштву јасно се уочава фолклорни подтекст, који представља значајан материјал за дубље проучавање традиционалних симбола. Ако погледамо временски период његовог стваралаштва (1904-1941), видећемо да је то време у којем су јужни крајеви још увек под турском влашћу. То је време Балканског и Првог светског рата, време кратког мира од 1918. до 1941. године и почетак Другог светског рата. У то време објављено је четрнаест књига Божовићеве прозе, али и много тога што је било расуто по књижевним часописима (Јеврић 2006: 9).

Григорије Божовић је скренуо пажњу на Србе у Старој Србији објављивањем своје прве збирке приповедака Из Сйаре Србије у Мостару 1908. године, која ће самим насловом скренути пажњу на тематику која је била ван домашаја књижевних кругова. Глас једног јужњачког писца није остао незапажен. Јован Скерлић ће писати о Старосрбијанцу Григорију Божовићу и Анђелку Костићу као два значајна писца и национална радника (Скерлић 1953: 427-28). У свој

2 „Али осим срдачне и увек живе везе са својим породичним прецима, човек динарског типа се осећа дубоко везан за своје националне претке: сматра да има још једну старију и славнију лозу, ону својих краљева и царева, својих славних јунака из доба Немањића и Косова, великих витезова, хајдука и ускока из турског времена, који су живели између Косова (1389. год.) и Карађорђева устанка (1814. год)“(Цвијић 1991: 343).

3 „Људи централног типа имају много такта и обазривости. Ретко се где у јужнословенским земљама људи мање вређају речима него у овој области и ретко се где увреде речима мирније сносе но овде. Штеде мане и слабости других и често крупним моралним погрешкама, лако прогледају кроз прсте кад се оне тичу „работе“. Умеју да владају собом: могу да зауставе осећања и жеље, да се предомисле и размисле; ретко има пренагљености; готово су увек смотрени и обазриви“ (Исто, 413). 
књижевни опус Григорије Божовић је транспоновао традиционално наслеђе које је било веома живо; обреде и обичаје, лирске и епске песме, народне приповетке (посебно предања) и говорне народне творевине (благослове, пословице и изреке).

Лирска и епска песма су фолклорни жанрови које је Божовић често уграђивао у своје прозно стваралаштво. Лирска песма која је спонтана „више или мање несвесна или подсвесна творевина“ (Ђурић 1965: 16) најчешће се чула на саборима и пољима где су се обављали земљораднички радови. Понекад је била медијатор између зараћених страна, док епска песма „служи за прослављање јунаштва“ (Матић 1964: 301). Читајући приповетке и путописе Григорија Божовића уочавамо његово добро познавање не само текста песама већ и истанчан осећај за мелодију. Његови јунаци певају углавном тужне песме, које су настале као архетипска наслага времена. Писац у својој путописној прози пише о средњовековном градовима који су били углавном у рушевинама, а који су у средњем веку грађени на неприступачном и доминантном терену (Detelić 2007: 10). Маркирани епски градови, о којима Божовић пише, углавном су повезивани с јунацима и они имају важну улогу у стварању њихове епске биографије. Транспоновањем епске песме у уметнички текст писац призива оно време када се певало „о коњима и о јунацима“ (Божовић 1990в: 13) доводећи у везу стварност и фикцију констатацијом да је путем у старом Расу „задњи пут бежао Сибињанин Јанко“ (Божовић 1990в: 7).

Транспозицију традиционалних симбола у уметнички текст Линда Хачион сматра једним од „неизбежних поступака“ (Hačion 1996: 18) у поетици постмодерниста. Тај „неизбежни поступак“ био је својствен и ранијим књижевним епохама. У прози Григорија Божовића уочавамо слојевитост у којој доминира историчност и фактографија; топоними, дијалекатско језичко богатство, етнолошки, етнопсихолошки, социолошки и фолклорни слој који је, како наводи Нортоп Фрај, важан да се „прошири на преостали део књижевности“ (Fraj 1979: 122).

У прози Григорија Божовића присутан је један сегмент који Веселин Чајкановић назива „клицање предака“ (Чајкановић 1994: 116) и писац то чини управо у оном слоју где се догађа транспоновање усменог наслеђа у облику лирске и епске песме, као и говорних народних творевина. Формуле фолклорног наслеђа представљају комуникацију с предачким наслеђем и оно је код Григорија Божовића увек у служби очувања идентитета, у средини у којој је српски живаљ свакодневно доживљавао зулуме што од Турака, што од Арбанаса. Усмено наслеђе у облику лирске и епске песме представљало је неку врсту уточишта и искорака из времена. Преко ових фолклорних облика ступало се у контакт са прецима који су својим присуством означавали фиктивни простор сигурности. Преко различитих облика 
усменог наслеђа преци су били у служби заштите колектива, кад се он нађе у невољи. Култ предака у приповеткама Григорија Божовића присутан је у току празника, и они „враћају свету димензију постојања" (Елијаде 2003: 126). Ове сакралне временске ритмове Григорије Божовић представио је као отклон од историјског времена, у којем је угрожена слобода и достојанствен живот колектива, а „подразумева излазак из 'свакодневног' временског трајања и уклапање у митско Време реактуализовано кроз празник“ (Елијаде 2003: 110).

Слика славе, свадбе, Божића, Васкрса, погреба који прати тужбалица, представља фактографску слику стања духа српског народа у првој половини XX века. У усменом наслеђу сачуван је древни облик архаичне свести који у свим културама, како наводи Бојан Јовановић, „наставља да живи у души и духовном животу људи и када су ти социо-културни услови престали да постоје“ (Јовановић 2000а: 222). На основу фолклорних записа, које је Григорије Божовић транспоновао у свој текст, стиче се увид у стање усменог казивања и богато традиционално наслеђе које је вековима имало важну функцију у очувању идентитета. Богато лирско наслеђе Старе Србије сачувано је у свести колектива као конзервирана архаична свест предака. Писац у свој књижевни опус уноси оне песме које су живеле у народу и које је слушао на многим путовањима по Старој Србији, Македонији и Црној Гори. Навешћемо овом приликом само почетне стихове песама које је писац забележио и ставио у контекст својих приповедака („Ој, ђевојко, ни ти право нећеш“ (Божовић 1990в: 12); „Не бојте се, тићи соколићи“ (Исто: 15); „Текла вода на валове“ (Исто: 19); „Идит момче од града“ (Исто: 99); „Темен се облак зададе“ (Исто: 101); „Распејал се Челник Пејо“ (Исто: 104); „Не седи, Џемо, слободен“ (Исто: 108); „Не ли ти реков, седи, не ходи, Џафер-аго“ (Исто: 109); „Ори Стојна, руса Стојна“ (Исто: 110); „Што ми је мерак пољак да бидам“ (Исто: 133); „Каури главе кренале“ (Исто: 134); „Ори Стојна, руса-Стојна“ (Исто: 144); „У кочији двије бедевије” (Исто: 155); „Горње Село стража ће ми чува”(Исто: 159); „Не иди в туђа туђина” (Исто: 182); „Винари Белограђани” (Исто: 192); „Како Струга нема друга” (Исто: 198); „Невесто, око калешо” (Исто: 199); „Што ми је мило и драго” (Исто: 200); „Новиграде, седиш накрај мора” (Исто: 213)). Транспозицијом лирске народне песме у своје дело писац дочарава етнопсихолошку слику средине у коју је сместио своје ликове, а који су пронашли свој одраз у тексту и мелодији песме.

Како је Григорије Божовић стварао на фону народне традиције, у свој књижевни опус инкорпорирао је оне симболе који представљају суштину колективне свести српског народа, а то су праг, огњиште и земља које налазимо и у народним песмама и у обредно-обичајној пракси. Праг у народној традицији Срба представља гранично место које дели унутрашњи део куће, који је под заштитом предака, од оног споља, где почиње опасност и где се заштита 
предака губи (Чајкановић 1994а: 414-422). Писац је у средини у којој је поникао имао колективну представу о значењу прага као табуисаног места. Њему се, као сакралном простору, прилазило с посебним поштовањем. Невеста је приликом уласка у младожењину кућу прескакала праг да не би повредила младожењине претке, а приликом изласка из своје куће љубила је праг да би се опростила од својих предака. Божовићеви јунаци, приликом уласка у кућу, строго воде рачуна да не стану на праг, као у приповеци „Неда Селогражданка“ где удовица, која је остала без мужа, приликом уласка у кућу „болно уздахну, па прескочи кућни праг и по навици несумице пође к огњишту“ (Божовић 19906: 19). Њен болни уздах, баш у тренутку прескакања прага, први је сусрет с домом, где свест о губитку мужа постаје јача. Прелазак из предела ван куће у предео унутар куће, где је граница праг, јасно се одразио на њено психичко стање и свест о губитку. Њен уздах, приликом преласка преко прага, када „насумице пође к огњишту“ представља први одраз туге пре сусрета са светом мртвих који обитава у огњишту. На истом том прагу, како каже Божовић, „звекнула је крвнина“, односно новац којим су Арнаути желели да откупе смрт њеног сина, да се не би наставила крвна освета. Зашто Арнаути бацају новац на Недин праг? Управо зато да би његов звекет „чули“ преци, који обитавају испод прага, да би дали неми благослов да се крвна освета, преко симболичне замене за жртву, заустави. Непријатељ, који у традиционалној култури Срба има атрибуте хтонског (Зечевић 2007: 13-17) не иде преко прага јер би у том случају значило освајање простора. У овој приповеци Арнаути долазе до куће, на праг бацају „крвнину“ и одлазе.

Григорије Божовић даје значај прагу и онда кад се тек потурчени Колашинац у приповеци „Љута православка“ враћа својој кући. Писац слика моменат уласка у кућу, кад га у драматичном тренутку сачекује жена која покушава да га одврати од турчења. На неки начин и праг добија функцију заштитника куће и предака. То видимо у тренутку кад тек потурчени човек размишља о томе како ће прећи преко прага, где ће га, после преверавања, први пут сачекати преци. Писац каже:

Још успут је слагао речи за прве поздравне реченице својем огњишту и својој породици како то нови његов закон прописује. Неће се гласнути испред куће, неће с прага натурити божју помоћ, но кад буде ушао унутра, кад га спазе, једро ће изговорити: „Селам алећ Турцима, а помози бог раји!“" (Божовић 19906: 82).

Потурчени члан породице није могао да не размишља о прагу кад улази у дом. Он зна да не може с прага да назове „Божју помоћ“ јер је изневерио претке. Праг је последња одбрана предачког завета. Улазак у кућу представља постепено освајање простора, док ће сусрет с прагом бити суочавање са сакралним простором које спреча- 
ва скрнављење дома. Он ће своју жену, која се опире турчењу, у тешкој ноћи, убеђивати да прихвати промену вере „ради овога прага и ђетета“ (Божовић 1990б: 83).

Божовић је, као и колектив у којем је поникао, видео праг као осетљив простор, сматрајући да се јунак доказује ван куће. Његово разумевање чојства видело се управо у односу према кућном прагу, односно према томе где се одређује простор за мегдан. У приповеци „Низ Голему“, писац каже: „уунаци не изненађују људе на њихову прагу. Никоговине и лупежи то раде. Јер је свако на прагу својем најосетљивији.“ (Божовић 1990в: 149). Праг, у народној традицији сакрални простор, означаван је, дакле, као место где се на основу односа према њему огледала вера и невера, односно карактер човека. Свако наношење зла на прагу представљало је узнемиравање предака, а самим тим свако непоштовање тог неписаног закона било је кажњено изопштавањем из колектива.

Кад гост у патријархалној култури прескочи преко прага, добија пуну заштиту домаћина. Уласком у кућу прихваћен је као брат или кум и добија атрибуте крвног или духовног сродства. ${ }^{4}$ Колико је Григорије Божовић у својим приповеткама водио рачуна о обичајној пракси говори његова констатација да су жене у патријархалној култури вековима имале задатак „само да гледају децу, оперу рубље и донесу на планину јунаку брашненике? Или да смирено дочекају на прагу госта и приме га као брата рођенога или кума крштенога?“ (Чајкановић 1994a: 283). Гост, као инкарнација митског претка, везује се за сакралност огњишта, а то значење је задржано и у прози Григорија Божовића.

Поред прага, у приповеткама Григорија Божовића посебно место заузима огњиште где обитавају „натприродна бића, највероватније домаћи духови, заштитници куће и укућана“ (Бандић 1991: 85-90). У српској традицији цео живот одвијао се поред огњишта. Ту су се догађале иницијације (рођење, свадба и смрт) и оно је било сакрални део куће где су се обављали важни разговори и доносиле важне одлуке. Као „средиште живота у сеоском домаћинству“ (Бандић 1991: 85), оно је у прози Григорија Божовића место преузето из традиционалне културе с непромењеним значењем.

Сви обреди прелаза (Генеп 2005) - рођење, свадба и смрт - подлежу строгом правилу. Све што се у приповеткама Григорија Божовића догађа око огњишта углавном је везано за иницијацију. Кад маркира огњиште, писац нас уводи у простор архаичног света, али

4 „U našim krajevima je odnos domaćina prema namerniku prevashodno bio obeležen težnjom da mu se ni na koji način ne zameri. Po opštem shvatanju, koje se do danas dobrim delom izgubilo, gostoprimstvo se nikome nije smelo uskratiti. Ne samo što se nije odbijao namernik, koji traži prenoćište, već ni prosjak, koji traži milostinju. Kad stranac, namernik, jednom dobije status gosta, on na izvestan način postaje neprikosnoven, tabuisan" (Bandić 1980: 356). 
у исто време оно представља простор око кога се окупља породица. Увођењем огњишта у причу долази до успоравања радње. Уколико се поред њега налазе предмети покућства, то ће бити углавном они предмети који указују на иницијацију. Тако ће у приповеци „Последњи оклопник“ поред огњишта стајати предмети које писац веже за славља која се очекују у кући („Око огњишта велике каце са шљивама да би се за свадбе и славе што пре испекла нова ракија, јер је старе нестало“ (Божовић 1990в: 8)). Григорије Божовић је често сликао ентеријер око огњишта и то у оним тренуцима кад домаћин прима госта у кућу. ${ }^{5}$ Он је најчешће оскудан и то је углавном совра на којој се обедовало („Око ниске округле совре постављене у кући до самога огњишта, јер друге светлости није било, шћућурила се као пилад готово полунага деца, женска и мушка" (Божовић 19906 : 42)). У народној традицији Срба постојао је обичај поздрављања огњишта, чиме се домаћин приликом уласка у кућу, на посредан начин, прво обраћао прецима да би их испоштовао и од њих примио благослов. У приповеци „Љута православка“ тек потурчени Колашинац, Милоје из Дубоког Потока, долази својој кући размишљајући како да прескочи кућни праг и поздрави огњиште крај кога га чека жена Богдана:

На детињу вриску Богдана се плаховито прену и спази надно куће, недалеко од врата, својега мужа. Збунио га синовљев поклич и стао укочен као стуб. Ни да коракне напред ни да изрекне какву реч. А науман је био да уђе одважно, да првим својим држањем освоји домаћицу и спасе себе од њених прекора. Преко руке је држао велике костретне бисаге, пуних разних дарова, чиме је мислио да збуни и жену и завара дете. Да му се обрадује, да га прими и да му лакше буде. Још успут је слагао речи за прве поздравне реченице својем огњишту и својој породици како то нови његов закон прописује. Неће се гласнути испред куће, неће с прага натурити божју помоћ, но кад буде ушао унутра, кад га спазе, једро ће изговорити: „Селам алећ Турцима, а помози бог раји!“ Међутим, родни праг био је јачи од нове заповести. Снага му се очас некако у камен претворила, а уста завезала од највеће страве. Пребледео, смутио се, те му још смешније дошле и шалваре и бедна чалмица око главе. Никад Богдана није могла ни сањати да је њен Милоје постао тако бедан Мустафа, не силни нови Турчин, но онај прави правцати Мустафа Циганин који по Колашину продаје котарице и проси (Божовић 1990б: 82).

Поред оњишта су доношене најважније породичне одлуке; ту се расправљало, мирило, спречавало турчење и дељење браће. За-

5 „У приповеци „Последњи оклопник“ писац слика атмосферу у кући свештеника, поред огњишта, у тренутку када уз благослов дочекује свога госта: „Познаде ме старац и свали с коња у наручје као дете. Загрли, благослови и одмах уведе у кућу. Она чиста, спремљена вазда као за славу, јер је кућа поповска, светска, коју посведневно посети ко не из бела света. Покрај огња стајао је готов троножни столац са наслоном и меким јастуком. Кад ме посади, он се усправи да по обичају с ногу још једном упита за здравље и изрекне снажну добродошлицу. По лику сушта слика проте Матеје Ненадовића“ (Божовић 1990в: 9). 
нимљиво је да је огњиште, као сакрални простор, био нека врста кућног олтара где су се окупљали углавном мушкарци. Кад су се водили разговори, жене су биле удаљене, негде у другом делу куће. Оне нису прилазиле када су „већале“ мушке главе. Сакралном огњишту, кад су мушкарци у кући, жени је био дозвољен приступ само онда кад је била уважавана, ритуално чиста, а то су углавном биле мајке у дубокој старости. У приповеци „Мајчин одвојац“ мајка прилази огњишту да спречи одвајање синова. Писац даје слику мушких глава које седе око огњишта јер је невоља закуцала на врата, и у тренутку уласка старе мајке у кућу „све што сеђаше око огња, устаде да стојећи дочека бабу“ (Божовић 1990б: 166). Домаћин се клања старици „као попу“, а традиционалан однос према огњишту видеће се и у тренутку кад она, иако ритуално чиста, због атрибута „старе мајке“, упозорава сина „да јој потури столицу до домаћинске: женска је страна иако мајка, неће да коби праг и огњиште“ (Божовић 1990б: 166). Григорије Божовић је из народне традиције у књижевно стваралаштво транспоновао устаљене облике обредно-обичајне праксе коју је познавао још од детињства. То се види у оним покретима и поступцима јунака који се углавном односе на праг и огњиште. У овој приповеци јасно је позициониран однос према овом сакралном делу куће. Праг је простор где се окупљају мушкарци, а строго одређено правило седања поред огњишта види се у поступцима и мушких и женских ликова. У овој приповеци на делу је обичајно правило да жена не седа поред огњишта ако су ту мушкарци. Иако укућани инсистирају да седне поред огњишта она, због уважавања мушког света, то право не користи.

Све што се догађало око огњишта имало је нечег обредног, било да је у питању рађање, свадба или смрт. Необична је јединствена слика у српској књижевности у приповеци „Кобни заточник“. После великих зверстава и освете која се догађа у кући Сокола Сенковића, пред очима његове жене и кћери осветник око огњишта игра коло, док поред њега лежи мртав домаћин: „У кући крај огња нашао је збуњеног Сокола Сенковића. Секиром га премлатио на очима његове жене и кћери. Па затим повео са њима тешко маћедонско оро око огњишта и измрцварена Сокола, певајући:

„Бурјано, Борјанке, сал ти ли си мома?...“

(Божовић 1990а: 153)

У свим патријархалним културама породица има важну улогу (Малиновски 1970). Код Григорија Божовића све је у служби њеног очувања. Посебно место писац је дао мајци, која у архетипском значењу има функцију Велике Мајке (Нојман 1994: 43-87) и која је стуб куће. Спречавајући домаћина да се потурчи, бежећи из своје куће „тамо, у Србију“, она постаје медијатор између света живих и мртвих, посебно кад треба оплакати покојника, чак и кад је туђин. Она 
преузима улогу мајке погинулог, која не може да ожали сина, и зато добија обележје заједничке, архетипске Велике Мајке. У приповеци „Неда Селогражданка“ писац прати судбину мајке која губи све синове, не желећи да заустави крвну освету. Њој се причињава да „преко прага ступи Стаменко са крвавим грудима и на устима, па је пита очима да ли јој је доста“ (Божовић 1990б: 23). Потпуно сама, она седи крај огњишта и пита се да ли је све требало баш тако и да ли је вредело. Размишља о клетви мајчином дојком коју је могла, као једину неприкосновену у народној традицији, да употреби да би спречила синове да „намире крв“. 6 Божовићеви женски ликови, посебно мајке, покушавају да врате „рајско време“ хармоничног живота. У његовој поетици оне су готово увек бранитељи традиционалног наслеђа, оне су, како би рекао Кајзер „нека врста споне између деце и мужа и пасивни посматрач“ (Кајзер 2002: 35-56). Мајке у приповеткама Григорија Божовића понекад добијају митолошке атрибуте и ону функцију коју су „богови или божанска бића учинила на почетку Времена“ (Елијаде 2003: 130).

Григорије Божовић је у своје приповетке транспоновао лирску и епску песму, предања, говорне народне творевине и друге жанрове народне књижевности. У успаванци, која је „заснована на магији речи“ (Пешић, Милошевић-Ђорђевић 1997: 252), а коју му у Дреници на албанском језику пева стара Урмелија, открива на крају српски језички палимпсест. ${ }^{7}$ Ако посматрамо Божовићеву поетику у светлу архетипске критике (Шутић 2000), уочавамо да су доминантни архетип јунака и мајке, уз сталан опозитан однос светло/тама, добро/

6 „Стара се поново стресе. Да ли је радила добро? Може бити да је ваљало друкчије? У туђем царству нема јунаштва. Многи то кажу, а Турци то утврдо држе. Нема ни срамоте, а? Да је имала покорније срце? Да је сваку потурицу смерно дочекивала? Да је дала земље, а сачувала синове? Па да је поклонила мужа и првога сина? Да их није светила, но замолила претекле синове у мајчино млеко да побацају своје пушке, или их предаду Кабашанима?... А може бити да је грехота што се тако држала? Рођену је децу узела на врат, сама појела као вештица..." (Божовић 1990б: 23).

7 „Поп Филип Гавриловић једва је раскравио своју тетку, стару Урмелију Соломонову да ми казује песме. Јасно сам видео као да се стиди што су те песме на арнаутском.

- По, не знам српско, бре господино, бре пустињо!... По, све, заборавио, а знао некад, знао оре пустињо, тако ми Бога знао!...

.... - О, пустињо, о господино! - узвикну на крају Урмелија: - по, кад сам био дете, сме певао и овако:

\section{Идит момче од града, \\ Мома била в ливада, \\ Ми заспала в ливада, \\ Со трева се покрила...}

Моје изненађење није имало граница. Па сам одмах спустио писаљку и одложио ненаписане листове. Погледао сам стару Урмелију на потпуно замагљене очи: биле су ми пуне суза. И ваистину божју, зарекао сам се да ћу сваког одмах шчепати за гркљан, ко само изусти да Горња Река није српска (Божовић 1990в: 99). 
зло, ми/они, тамо/овде... Традиционална култура која је, како наводи Ерих Нојман „обликовала духовни свет свих народа“ (Нојман 1994: 92) није могла а да се јасније не одреди према култу земље. Ослањајући се у свом стваралаштву на митске представе ${ }^{8}$ свог краја, Григорије Божовић је на трагу става Елеазара Мелетинског који каже да се у стварању једног писца требало ослонити „на вечно живу митску основу у самој уметничкој уобразиљи, у психологији писца" (Meletinski 1983:105). У пишчевом индивидуално-несвесном одражава се колективно несвесно у коме значајно место заузима однос према земљи, посебно у прилици угрожености етнопсихолошке заједнице. Стварајући у духу народне традиције, писац је инкорпорирао оне слојеве народне свести који су у свакој традицији непроменљиви и константни (Јовановић 2014: 38). У пишчевом опусу постоји стална потреба за успостављањем реда, који је нарушен доласком Турака, и хармонијом којој теже све древне цивилизације (Елијаде 2003: 110-126).

Како је писац био укорењен у традицију косовског поднебља неизбежно је да у његовом књижевном стваралаштву посебно место заузима култ земље, која је у свести многих народа имала посебно значење. ${ }^{9}$ Тај однос је архетипски. Земља има атрибуте Велике Мајке према којој човек има посебан однос. ${ }^{10}$ Култ земље код Григорија Божовића увек је везан за култ предака и она је одређена атрибутом „дивна“ („Има дивну своју земљу, прикупљену и од дедова наслеђену” (Божовић 1990а: 88)), али је отимају Турци и Арнаути („Али аге и Арнаути хоће његову земљу“ (Божовић 1990а: 89)). Писац је искон-

8 „Славонски бан заиста је помагао великом мађарском војводи у последњој његовој бици са Турцима код данашњег Обилићева на Косову. Прича се да је био рањен и понет из боја, ту код Грубетића умро и сахрањен. Али ја не пођох да се уверим. Непосредно преда мном беше се натмурио Црни Врх, највиша тачка тешко проходне Рогозне. Зарадовах се као дете, јер га нисам никада овако из близине посматрао. То је Олимп мојега краја за који су везане бајке, приче, муње и облаци. Још по нешто од тога памтим. На врху му је мало језеро. Оно је сад за путника сасвим обично. А некада су из њега излазиле прикојасе, црни бикови, чудновати овнови, праћакале се велике змијурине, виле окретале коло и прикупљале лековите траве кад би наступиле међудневнице. Мало је од тога остало. Али опет остало“ (Исто, 7).

9 Zemlja „Velika majka; majka zemlja; univerzalna roditeljka; hraniteljka; starateljka. Majka zemlja je univerzalan arhetip rodnosti, neiscrpnog tvoraštva i sredstava za opstanak. Zemlja i nebo su materija i duh. Indijanska tradicija: zemlja je majka; loža zemunica je omfal, vaseljensko središte. Kružni joj pod prikazuje zemlju, kupolasti krov nebesa, a četiri koca su zvezde i četiri pravca. Keltska: kvarljivo telo, uz so kao besmrtni duh. Zemlja je stavljana na grudi mrtvima. Kineska: ženski, jinski princip, simbolizovana kvadratom, žutom bojom i tigrom“" (Kuper 1986: 191).

10 „U svim društvenim zajednicama koje svoju egzistenciju zasnivaju na zemljoradnji stvara se specifičan, mističan odnos ljudi prema materijalnoj podlozi njihovog opstanka - zemlji... Opšte je pravilo da se mesto na kome počivaju čovekovi posmrtni ostaci zamišlja kao stan njegove duše (na primer, grob, prag, ognjište). Prirodno je onda što se u zemljište koje pripada određenoj društvenoj zajednici (u našim uslovima, najčešće kućnoj zajednici, domaćinstvu) smatralo sedištem njenih pokojnika i predaka. Prisustvo mrtvih u zemlji čini ovu „svetom i neprikosnovenom“ (Bandić 1980: 295). 
ску везаност за земљу показао у оним тренуцима када су Срби изложени притиском да је напусте. У његовим приповеткама посебан однос према земљи имају Моравци из гњиланског краја. У приповеци „Оклопник без страха и мане“ писац је задивљен истрајношћу старог Мојсила Златановића „из села Каменице у Горњој Морави, испод Новога Брда“ (Божовић 1990а: 88). Његов однос према земљи представља нераскидиву везу с култом предака. Веровало се да одлазак с ње представља напуштање предака који обитавају тамо где је огњиште. Мојсил Златановић, који има седамдесетак година, долази у митрополију у Приштину и својим ставом према земљи задивљује Божовића и Милана Ракића, српског конзула у тадашњој Турској. Нигде писац није тако јасно, као преко овог Моравца, показао прави однос Косоваца према земљи, као и према Србима у централној Србији која је тада била слободна. Мојсилово казивање у први план ставља земљу, али и култ госта, питајући се зашто би његов син бежао у Србију: „Викам, господине, зашто да бега у Србију? Србија има доста људи, а ова јој земља ваља, а ми смо, вика, тапија за њу. Кад дође овамо, па никога од нас не нађе - ће гу врате натраг, зашто ће јој рекну: „Ето, нема овде нико твој - неје ово твоје“ (Божовић 1990а: 89). Задивљен везаношћу Моравца за земљу, писац прати његово разложно и емотивно казивање о томе како му аге и Арнаути прете и нуде велики откуп:

Не да он земљу, не да је ни за какве паре. И неће да је остави. Земља му је мајка, држи га она неким чудним благословом, те је готов да њу натопи крвљу својом и своје деце. Остаће на њој когод жив да дочека Србију... Но стар сам, деце немам више, унучади не. Ће остане пуста земља. А њу жалим. Притиснуће је душманин, па ми је тешко да умрем, а нико мој да не дочека мајку Србију, ту, где ми се родија дедо и татко, где смо сви плакали и молили бога - ту да је дочекамо... Неје време за плакање, мој синко!... Ја сам дошаја код вас не да жалимо моје синове и да кукамо овде, но да тражимо нека врата, неки дерман...Ја сам своју бабовину ухватија зубима, ете овако, и жив од ње не се одвајам. И сад... и сад... не плачите, а да нађемо некога ко ће као ја да легне снажно на њу, да је ухвати зубима и да је тако не испушта док не дође она... одозго“ (Божовић 1990а: 89-90).

Сликајући везаност Косоваца за земљу Божовић користи синтагму: „То су они који за робовања зубима држаше земљу нашу“ (Божовић 1990а: 93) или „Земља ме ова вуче као да сам влачезима за њу привезан“ (Божовић 1990а: 103), што представља остатак архаичне свести о човековој везаности за архетипску представу земље као Beлике Мајке,.

Божовић је уочио да однос према земљи није исти код свих Срба, имајући у виду варијетете о којима је писао Јован Цвијић (посебно у односу на централни и динарски варијетет). Средина у којој је писац рођен припадала је динарском варијетету, али је он с дивљењем посматрао Моравце који припадају централном типу, који имају 
посебан однос према земљи. Писац у својим приповеткама повремено учитава свој суд о значајним појавама у колективној свести Косоваца. Он ће у приповеци „Два мученика“, сликајући Моравца из гњиланског краја, показати његов начин одевања, али и духовне особине где доминира „рејетински притајен“ израз лица. Григорије Божовић и Милан Ракић задивљени су односом овог Моравца према земљи, наглашавајући да Динарце увек обрадује сусрет с оваквим људима: „Чини ти се да је прирастао за земљу и да га с места не би могао померити док је у њему живота, само ако је одлучио да га брани“ (Божовић 1990а: 134).

Патријархални свет о коме пише Григорије Божовић представља оквир у који писац смешта своје ликове. Пишући о том слоју Божовићевог приповедања, Милисав Савић запажа да „не мисли Божовић да се свет држи на народним причама и пословицама, или на обичајима који полако нестају, нити у чистом, свечарском, здравичарском народном језику, али наговештава читаоцу да се тај у много чему затворени, ванвременски свет, свет из епских времена, не може разумети без неких старинских обичаја који још увек у њему трају и имају вредност“ (Савић 2006: 35).

У слојевитом књижевном опусу Григорија Божовића фолклорни подтекст је само један од могућих тумачења. Проучавањем архетипских слојева његовог стваралаштва, уз интердисциплинаран приступ, стекао би се нов увид у поетику овог значајног писца. О потреби за проучавањем његовог опуса указао је још Станислав Винавер, рекавши да је дошло време да се читалачка публика „најзад обавести о лепоти и слави и јаду свога крвавога и ропскога југа, и то не из фалсификованих и отужних извора, већ на моћноме и бистроме врелу које му је, својом књигом, у досад недоступноме кршу, отворио Г. Божовић“ (Винавер 1924: 4). Винаверово скретање пажње на књижевни опус Григорија Божовића представља усмеравање научних истраживача на ново читање и тумачење овог значајног писца с југа који је, транспонујућу традиционалне слојеве српске културе у своје стваралаштво, оставио драгоцене податке о традиционалној култури Срба у Старој Србији.

\section{ИЗВОРИ}

Божовић, Григорије. Неизмииљени ликови. Приштина: Јединство, 1990а. „---“. Робле заробльено. Приштина, Јединство, 19906.

„---,. Чуgесни куйови. Приштина, Јединство, 1990в. 


\section{ЛИТЕРАТУРА}

Вученов, Димитрије. Траі̄ом ейохе реализма. Крушевац: Багдала, 1981.

Бандић, Душан. Нарояна релиіија Срба у 100 йојмова. Београд: Нолит, 1991.

Bandić, Dušan. Tabu u tradicionalnoj kulturi Srba. Beograd: BIGZ, 1980.

Винавер, С. „Са крвавога и жалнога југа, приповетке Гр. Божовића“. Време 28. VII 1924: 4.

Генеп, Ван. Обреgи иррелаза. Превела Јелена Лома. Београд: СКЗ, 2005.

Detelić, Mirjana. Epski gradovi. Beograd: SANU, 2007.

Ђурић, Војислав. Лирика. Београд: Завод за издавање уџбеника Социјалистичке Републике Србије, 1965.

Елијаде, Мирча. Свет̄о и йрофано. Превео с француског Зоран Стојановић. Нови Сад:

Издавачка књижарница Зорана Стојановића Сремски Карловци, 2003.

Зуковић, Љубомир. „Трагови народних песама у прози Григорија Божовића“. Језик и сииил Гриїорија Божовића. Ур. Драгиша Бојовић. Косовска Митровица: Филозофски факултет; Зубин Поток: Стари Колашин, 2006. 123-132.

Зечевић, Слободан. Мийска бића срӣских йреgаға. Београд: Службени гласник,1983.

Јовановић а, Бојан. Дух йаїанскої наслеђа у срӣској йраgищионалној кулитури. Нови Сад: Светови, 2000.

Јовановић, Бојан. Памћене и самозаборав. Нови Сад: Orpheus, 2014.

Јеврић, Милорад. „Григорије Божовић на међи стилских епоха“. Језик и сииил Гриіорија Божовића. Ур. Драгиша Бојовић. Косовска Митровица: Филозофски факултет; Зубин Поток: Стари Колашин, 2006.9-23.

Кајзер, Карл. Порояица и сроgсивво на Балкану. Београд: Удружење за друштвену историју, 2002.

Kuper, Džin Kembel. Ilustrovana enciklopedija tradicionalnih simbola. Preveo Slobodan Đorđević, Beograd: Prosveta-Nolit, 1986.

Матић, Светозар. Наш нароgни ей и наш сйих. Нови Сад: Матица српска, 1964.

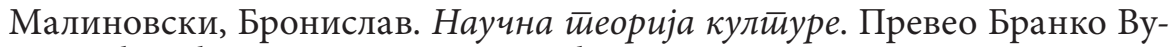
чићевић. Београд: Вук Караџић, 1970.

Meletinski. Eleazar. Poetika mita. Preveo Jovan Janićijević. Beograd: Nolit, 1983.

Нојман, Ерих. Истиоријско йорекло свесӣu. Превео Григорије Ерњаковић, Београд: Просвета, 1994.

Пешић, Радмила и Милошевић-Ђорђевић Нада. Нароgна кюижевности. Београд: Требник, 1977.

Савић, Милисав. „Документарно, фолклорно и романтичарско у приповеткама Григорија Божовића“. Језик и сииил Гриіорија Божовића. Ур. Драгиша Бојовић. Косовска Митровица: Филозофски факултет; Зубин Поток: Стари Колашин, 2006. 33-38. 
Скерлић, Јован. Истиорија нове срйске къижевносиии. Београд: Рад, 1953. Ћосић, Бранимир. „У разговору са Григоријем Божовићем“, Београд: Реч и слика, 1927.

Frye, Northrop. Anatomija kritike. Prevela Giga Gračan. Zagreb: Naprijed, 1979.

Hačion, Linda. Poetika postmodernizma. Prevod Vladimir Gvozden i Ljubica Stanković. Novi Sad: Svetovi, 1996.

Цвијић, Јован. Балканско йолуостирво. Београд: САНУ, Завод за уџбенике и наставна средства, Новинско-издавачка радна организација „Књижевне новине“, 1991.

Чајкановић, Веселин. Сӣуgије из срӣске релиїије и фолклора 1925-1942. Београд: СКЗ, БИГЗ, Просвета, Партенон М. А. М, 1994.

Чајкановић а, Веселин. Сйуgије из срӣске релийије и фолклора 1910-1924. Београд: СКЗ, БИГЗ, Просвета, Партенон М. А. М, 1994.

Шутић, Милосав. Кюижевна архейийолоїија. Београд: Институт за књижевност и уметност, 2000.

Valentina Pitulić

The Narrative Prose of Grigorije Božović in the Light of the Tradition

The Meaning of the Threshold, the Fireplace and Earth

Summary

In the works of Grigorije Božović, there is a layer of traditional culture that the writer transposed from the patriarchal environment in which he had grown up. This refers to examples of ritual and customary practice that played an important role in preserving the identity of the Serbian people in Kosovo and Metohija. The folklore subtext, which is very important for understanding the ethnopsychological community Božović writes about, is dominated by oral forms of collective heritage, such as lyric and epic poems, legends as well as other spoken folk forms.

The paper deals with the function of transposing archaic forms of collective consciousness, such as the threshold, the hearth and the earth, into a literary text. The writer conveyed these sacred places retaining the same form and meaning which they possessed in the collective consciousness of the patriarchal community. In other words, in Grigorije Božovićs opus, the threshold, the hearth and the earth have the same meaning they had in the ritual and customary practice. The author introduced an entire layer of folk heritage into his poetics, thereby creating a clearer picture of the collective community which managed to preserve its identity under Turkish rule for a long time by engaging in these forms of traditional culture.

Keywords: lyric poem, epic poem, threshold, hearth, guest, earth, Serbs, Turks, Arbanasi

Примљен: 7. 3. 2020.

Прихваћен за објављивање: 15. 9. 2020. 